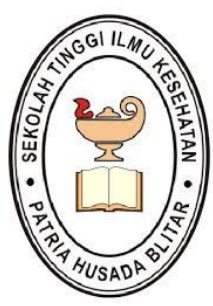

JNK

JURNAL NERS DAN KEBIDANAN (JOURNAL OFNERS ANDMIIDWIFERY) http://jnk.phb.ac.id/index.php/jnk

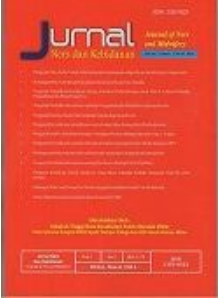

\title{
The Impact of Reproduction Health Education Using Peer Mentoring Method Towards the Knowledge Level of Patients with Sexuality Transmitted Infection
}

\author{
Yanuar Eka Pujiastutik ${ }^{1}$, Putri Kristyaningsih ${ }^{2}$ \\ ${ }^{1,2}$ Nursing Department, Faculty of Health, Institut Ilmu Kesehatan Bhakti Wiyata Kediri, Indonesia
}

\begin{abstract}
Article Information Abstract
History Article:

Received, 30/08/2021

Accepted, 19/11/2021

Published, 15/12/2021

Keywords:

Health Education, Peer Mentoring Methods, Knowledge, Sexually Transmitted Infections

Sexuality transmitted infections are often also reffered to as veneral diseases. The spread can be from blood, sperm, or can also be transmitted from mother to fetus during pregnancy and birth, and through the blood and body tissues. In addition, spread can also without sexual intercourse, it can be from the use of syringes repeatedly or alternately, among people, as well as the risk of transmitting infection. The aim of this study was to determine the influence of reproduction health education using peer mentoring method towards the knowledge level of patients with sexuality transmitted infection. The study used one group pretest-posttest design. The data was collected by using a questionnaire. The respondent was selected by using total sampling technique and 27 respondents were obtained. The data was analyzed by using the Wilcoxon test. The result of the $\square$ value $=0,000$, which meant $\square$ value $<\alpha(\alpha=0.05)$ there was an effect of reproduction health education using peer mentoring method towards the knowledge level of patients with sexuality transmitted infection. For researchers, next expected can be used as information to developed a method of information in other research.
\end{abstract}

C 2021 Journal of Ners and Midwifery

\footnotetext{
Correspondence Address:

Institut Ilmu Kesehatan Bhakti Wiyata Kediri - East Java, Indonesia

P-ISSN : 2355-052X

Email: yanuar.eka@iik.ac.id

E-ISSN : $2548-3811$

DOI: 10.26699/jnk.v8i3.ART.p284-289
}

This is an Open Access article under the CC BY-SA license (http://creativecommons.org/licenses/by-sa/4.0/) 


\section{INTRODUCTION}

Sexuality transmitted infections (STI) also known as sexual disease, is a disesase that was transmitted through unsafe sex. It can spread from blood, sperm, or from mother to fetus during the pregnancy and birth, and also from blood and body tissue, the usage of syringe that alternate in some people. The types of TSI are gonorrhea, syphilis, clamydia trachomatis, Genital Herpes, vaginal trichomoniasis, chancroid, kandiloma akuminata, HIV and Hepatitis B (Kemenkes RI, 2013).

STI can transmitt from one person to another person by doing the sexual contact. In indonesia, the STI are gonorrhea and syphilis. One of STI that can not be heal yet is HIV / AIDS. The spreading of HIV can occur by some factors, there are free sex behaviour, decendent of religion value, lifestyle, occupation, and the failure in marriage (Sari, 2015).

World Health Organization (WHO) estimates that about 350 million new STI cases (Syphilis, Gonorrhea, Klamidia, and Trikhomonas) occur in the world for every year. In correlation with HIV/ AIDS infection, on 1995 United States Bureau Of Census conveys, the district with the high STI prevalence, the prevalence of HIV/AIDS also on the high level and it was found the high risk sex behaviour (Noviyani, 2017).

From the data, STI clinic visit, it was known that the proportion of STI in District of Kediri is high. For the last three years, the incident of STI does not decrease, it is $69,44 \%$ on $2011,62,78 \%$ on 2012 , and $64,62 \%$ on 2013. And it is trend to rise on 2013. The STI diagnoses on District of Kediri in 2013 were dominate by servicitis for about $42 \%$, candidiasis for about $10,8 \%$, siphylis for about $4,3 \%$ and tricomoniasis for about 3,4\% (Kediri Health Departement, 2013).

From the earlier study on Balowerti Public health Centre City of Kediri, Balowerti has been educating patients but not maximally. On December $29^{\text {th }} 2019$, the amount of patient with STI on October 2019 is 34 cases, and November 2019 is 44 cases, and December 2019 is 2 cases. From that data, it shows the increasing of STI case on Balowerti Public health Centre City of Kediri.

Some factors can cause the increase of STI case, one of them is internal factor. The internal factors consist of that can influence the increase of STI are age when the firs sexual activity, education, less knowledge about the risk of STI, marital status, the sum of sexual partner and the occupa- tion as commercial sex worker (Nari, 2015). Person who has high risk to contaminated by the STI is person who often change the sexual partner and do the sexual activity without using condom. Risky behaviour also can increase the spread of STI, it is by doing unsafe sexual contact with the person who already infected with STI. Changes in views on sexuality are thought to have caused a major shift in sexual habits and lifestyles that tend to deviate towards negative habits (Najmah, 2016).

Sexual Transmitted Infection disease could not be trivial, because it has some effects, there are the damage of reproduction organs, neural damage, transmitted to the fetus while pregnancy, and the worst is it can cause death (Herawati, 2007).

The government's effort in overcoming the problem of sexually transmitted infections is to make preventive efforts by providing health education that involves all health workers, especially nurses. Nurses are one of the health workers whose job is to provide education to the community. This role is carried out by assisting the client in increasing the level of health knowledge, symptoms of the disease and even the therapy that has been given, so the behaviour can change and the increase of knowledge. But even though the government has made these efforts, the incidence of STIs is still increasing (Aulia, 2014).

Health education about health reproductive knowledge must be owned by everyone, one of it is to avoid sexually transmitted infections. Sufficient knowledge must also be equipped with self-awareness to protect oneself so as to prevent or at least minimize these risks. As for the things that you can do, among others, always use a condom when having sex, maintain the cleanliness of the sexual organs, and regularly check with the doctor (KPAN, 2010).

According to Notoatmodjo (2012), health education is an effort to improve learning for the community to maintain, maintain and improve their health. Health education can also provide knowledge about health activities and actions for health workers and prospective health workers who are still in their education period. The expected result of a health education is an increase in health behavior, or behavior to maintain and improve conducive health.

One method that can be used in health education is to use the Peer Mentoring method. Peer mentoring is placing mentees to get mentors from 
friends in the mentoring group (Noorwod, 2010). Peer mentoring is someone who has the same job responsibilities as the mentee, but the peer mentor has slightly more experience or is someone one level above the mentee (Kim and Zabelina, 2011). Thus, the mentee is easier to accept the learning process provided by peer mentoring because there is no reluctance or shame to ask questions (Grant, 2015). It is hoped that using the peer mentoring method by providing reproductive health education with peer mentoring methods, the level of knowledge of sexually transmitted patients can increase.

\section{METHODS}

This study used Pre-experimental design using one group pretest-posttest design. The study location was carried out in the Balowerti Health Center area of Kediri City for 1 month. The respondent was selected by using total sampling technique. There were 27 respondents became the sample. The independent variable in this study was reproductive health education using the peer mentoring method. In obtaining information from respondents, the researchers used a research instrument in the form of a questionnaire containing 20 statements about knowledge of sexually transmitted infections. The results of the validity test showed that the value in the Corrected Item-Total Correlation column got a value $>r$ table $(0.444)$, which meant it was valid. While the reliability test on 20 respondents with a Cronbach's Alpha value of $0.760>$ r table (0.444) so that it was reliable. The data was analyzed by the Wilcoxon test. At the implementation stage, the researcher determined one of the respondents to be used as peer mentoring according to the peer mentoring criteria, namely a friend in the mentoring group, someone who was appointed by the mentor as peer mentoring and had more or less experience from the mentee. After being given reproductive health education using the peer mentoring method, it is expected that knowledge about reproductive health in sexually transmitted infection patients can increase to provide reproductive health education to respondents.

\section{RESULT}

The results of the study for 1 month in the Balowerti Health Center area of Kediri City, have passed the number ethics decorent 760/PP2M-KE/ April/2020. Test obtained data on the characteristics of the respondents as below:

Table 1 Frequency distribution by age, gender, education level, source of information

\begin{tabular}{lcc}
\hline Variables & Frequencies & Percent $(\boldsymbol{\%})$ \\
\hline Age: & & \\
17-25 years & 8 & 29.6 \\
26-35 years & 5 & 18.5 \\
36-45 years & 10 & 37.0 \\
46-55 years & 4 & 14.8 \\
\hline Sex: & & \\
Male & 0 & 0 \\
Female & 27 & 100 \\
\hline Knowledge level: & & \\
Elementary & 2 & 7.4 \\
Junior High School & 9 & 33.3 \\
Senior High School & 16 & 59.3 \\
\hline Information & & \\
sources:Internet & 9 & 33.3 \\
Family & 5 & 18.5 \\
Health Workers & 13 & 48.1 \\
\hline
\end{tabular}

Source : primary data

Table 2 Frequency Distribution of Knowledge Levels Before and After Being Given Reproductive Health Education Using The Peer Mentoring Method

\begin{tabular}{|c|c|c|c|c|c|c|c|c|}
\hline \multirow{3}{*}{ Intervention } & \multicolumn{6}{|c|}{ Knowledge level } & \multirow{2}{*}{\multicolumn{2}{|c|}{ Total }} \\
\hline & \multicolumn{2}{|c|}{ Good } & \multicolumn{2}{|c|}{ Enough } & \multicolumn{2}{|c|}{ Less } & & \\
\hline & $\mathbf{n}$ & $\%$ & $\mathbf{n}$ & $\%$ & $\mathbf{n}$ & $\%$ & $\mathbf{n}$ & $\%$ \\
\hline Before & 0 & 0 & 6 & 22,2 & 21 & 77,8 & 27 & 100 \\
\hline After & 20 & 74,1 & 5 & 18,5 & 2 & 7,4 & 27 & 100 \\
\hline
\end{tabular}

Source : primary data 
The average level of pre-intervention knowledge was 1.22 while the post-intervention average was 2.67. There is a difference in the average level of knowledge pre-intervention and post-intervention so that there is an increase of 1.45. In the Wilcoxon statistical test analysis, it shows the value of value $=0.000$, which means $<(\alpha=0.05)$, then $\mathrm{H} 0$ is not accepted and $\mathrm{H} 1$ there is an effect of reproductive health education using the peer mentoring method on the knowledge of sexually transmitted infection patients in the Balowerti City Health Center area Kediri.

\section{DISCUSSION}

\section{a. Identification of knowledge of sexually transmitted infection patients about reproductive health prior to reproductive health education using the peer mentoring method}

Based on the research data of respondents aged 36-45 years, most of the last education level is only junior high school, causing the level of knowledge of respondents is still lacking. This is in line with the explanation. Dharmawati and Wirata (2016) that, there is a relationship between the level of education and the level of knowledge because it cannot be denied that the higher a person's education, the higher the level of receiving information and the more knowledge one has. On the other hand, if someone has a low level of education, it will hinder the development of a person's attitude towards receiving information and values that have just been introduced.

Based on the research, the sources of information about reproductive health that were previously obtained by the respondents were 9 respondents $(33.3 \%)$ from the internet, 5 respondents (18.5\%) from the family, and 13 respondents $(48.1 \%)$ from the health worker. Sources of information greatly affect respondents because good information will provide knowledge to respondents and can change respondents' attitudes. People who are exposed to sources of information produce increased knowledge when compared to people who are not exposed to sources of information (Yusra et al, 2016). According to Rohmawati (2011) in Taufia (2017) exposure to health information on individuals will encourage health behaviour.
To convey information about health and improving the quality of life for the community, information should be obtained from experts and it is necessary to have reliable communicators in the health sector, including health workers, such as nurses, doctors, midwives, and others (Prasanti \& Indriani, 2017 ).

The role of health workers is very important because health workers have very high trust in the community and are a visible and competent source of information for clients who want to improve their physical and psychological conditions. Health workers provide information and skills and can change people's behavior to be healthier. This can be done at school, home, clinic or workplace (Potter \& Perry, 2009).

\section{b. Identification of knowledge of sexually transmitted infection patients about reproductive health after reproductive health education using the peer mentoring method}

Based on data from the results of research conducted, it is known that the level of knowledge possessed by respondents after being given reproductive health education is 20 respondents $(74.1 \%)$ have good knowledge, 5 respondents $(18.5 \%)$ have sufficient knowledge and 2 respondents $(7,4 \%)$ have less knowledge. The results of the study indicate an increase in the knowledge of the respondents, namely that most of the respondents have good knowledge. This can be seen from the reduced number of respondents with a low level of knowledge, namely as many as 2 respondents (7.4\%)

The Peer Mentoring method is to place a mentee to get a mentor who comes from a friend in the mentoring group. Peer mentoring is someone who is appointed by the mentor as peer mentoring in providing guidance or learning to friends in the mentoring group. Peer mentoring has the same job responsibilities as the mentee, but the peer mentoring has had slightly more experience or someone is one level above the mentee (Rhodes, 2011). Thus, the mentee is easier to accept the learning process provided by peer mentoring because there is no reluctance or shame to ask questions. In addition, peer mentoring can enhance social ties to the mentee in the learning process that will be carried out. This 
type of method is also useful for solving a problem (Grant, 2015).

According to research conducted by Sulistiyowati (2009) on the analysis of the implementation of peer mentoring in the formation of selfconcept of high school students at the ILNA youth center in Bogor. The research results obtained that the implementation of peer mentoring can increase knowledge, spirituality, social and psychology for students in developing self-concept (Ismail et al., 2015). With the conclusion that the implementation of mentoring is very effective as a method of guidance for adolescents in developing self-concept in increasing knowledge, spirituality, and social and psychology.

\section{c. Analysis of the effect of reproductive health education using the peer mentoring method on the knowledge of sexually transmitted infection patients in the Balowerti Health Center area of Kediri City}

In this study, the Wilcoxon test was used to analyze the observations from the two data before and after the intervention, whether they were different or not. By using the Wilcoxon test, this study gives the results of value $=0.000$, which means value $<(\alpha=0.05)$, where $\mathrm{H} €$ is rejected and $\mathrm{H} 1$ is accepted so that there is an effect of reproductive health education using the peer mentoring method on the knowledge of infectious infection patients in the area of Balowerti Health Center, Kediri City. In addition, the average difference in pre-intervention knowledge levels is 1.22 while the post-intervention average is 2.67 . There is a difference in the average level of knowledge pre-intervention and post-intervention so that there is an increase of 1.45.

These results are supported by the conclusions of the results of research conducted by Sari and Oktaviani (2015) with the title the effect of reproductive health education using the peer mentoring method on adolescent knowledge about reproductive health where it can be concluded that there is an effect of reproductive health education with peer mentoring methods on reproductive health knowledge in adolescents. youth of SMPN 4 Palembayan. This is evidenced by the increase in the average before the intervention was given, which was 16.02 while after the intervention it was 77.43. This means that there is a difference in the average knowledge before and after the intervention, which is 16.41 .
Research conducted by Suminar and Anisa, 2020 with the title the effect of peer education menstrual health toward students readiness facing early menstruation where it can be concluded that there is differences between the readiness of students before and after menstrual health peer education interventions Paired $T$ test results obtained a significance value of $0.003(\mathrm{p}<0.05)$.

\section{CONCLUSIONS}

The level of knowledge of respondents before being given reproductive health education using the peer mentoring method, it was found that most of the respondents had a category of poor knowledge, while after being given, it was found that most of the respondents had good knowledge categories and after being tested there was an effect of reproductive health education using the peer mentoring method. for patients with sexually transmitted infections.

\section{SUGGESTIONS}

For Balowerti Health Center area of Kediri City can be used development of peer mentoring as a method of health education to reduce morbidity and mortality.

\section{REFERENCES}

Aulia, E. (2014). Peran dan fungsi perawat komunitas sebagai pendidik. Juni 6, 2014. Diakses dari https:// groups.google.com

Dharmawati, A. I. G. A. \& Wirata, I. N. (2016). Hubungan Tingkat Pendidikan, Umur, dan Masa Kerja. Jurnal Kesehatan Gigi, Volume 4, p. 2.

Dinas Kesehatan Kabupaten Kediri. (2013). Laporan Kejadian Infeksi Menular Seksual. Kediri: Bidang $\mathrm{P} 2 \mathrm{P}$.

Grant, C.S. (2015). Mentoring: empowering your sucess. in: grant PAPS, Editor. Success Strategies From Women in STEM (Second edition). San Diego: Academic Press.

Herawati, Y.E. (2007). Hubungan Antara Pengetahuan Tentang

Penyakit Menular Seksual dan Sikap Terhadap Seks Bebas.

Pada Remaja Akhir. Skripsi (tidak dipublikasikan). Semarang: Fakultas Psikologi Universitas Kristen Soegijapranata.

Ismail,A.,Abdulah,N.,Zaedy,NI.,Ghani,AA.,Omar,N. (2015). Mentoring Program as an Instrument of Enhancing Mentees' Self-Efficacy. Acta Universitatis Danubius. Communicatio, Vol 9, No 1. 
Kementrian Kesehatan Repubik Indonesia. (2013). Pedoman Nasional Tes Dan Konseling HIV Dan AIDS. Jakarta: Kementrian Kesehatan Republik Indonesia.

Kim, K.H., \& Zabelina, D.L. (2011). Mentors in: pritzker marr, editor. Encyclopedia of Creativity (Second Edition). San Diego: Academic Press.

KPAN. (2010). Strategi dan Rencana Aksi Nasional Penanggulangan HIV dan AIDS. KPA. Depkes RI.

Najmah. (2016). Epidemiologi Penyakit Menular. Jakarta: Trans Info Media.

Nari, J. (2015). Analisis Faktor-Faktor yang Berhubungan dengan Kejadian IMS pada Remaja di Klinik IMS Puskesmas Rijali dan Passo Kota Ambon. Jurnal Promosi Kesehatan Indonesia, Vol. 10 / No. 2 : 131143.

Norwood, A.W. (2010). The Lived Experience of Nurse Mentors: Mentoring nurses in the proffesion. Disertasi. Missouri: Faculty of The Graduate School University of Missouri-Columbia.

Notoatmodjo, S. (2010). Metodologi Penelitian Kesehatan. Jakarta : Rineka Cipta.

Notoatmodjo, S. (2015). Promosi kesehatan dan Perilaku Kesehatan. Jakarta: Rineka Cipta.

Notoatmodjo, S. (2015). Metodologi Penelitian Kesehatan. Jakarta : Rineka Cipta.

Noviyani, D. (2017). Perilaku Sekszual Berisiko Infeksi Menular Seksual (IMS)

Pada Kelompok Lesbi Di Kota Semarang. Journal of Health, Vol 2 (2) : 122-129.

Oktaviani, T., dkk. (2015). Pengaruh Pendidikan Kesehatan Reproduksi Menggunakan Metode Mentoring Terhadap Pengetahuan Remaja Tentang

Kesehatan Reproduksi. Ners Jurnal Keperawatan. Volume 11, No 1, 41-51.
Potter \& Perry. (2009). Fundamental Keperawatan. Edisi 7. Jakarta: Salemba Medika.

Prasanti, D., Fuady, I., \& Indriani, S.S. (2017). Optimalisasi Bidan Desa Dalam Penyebaran Informasi Kesehatan Bagi Masyarakat di Kabupaten Bandung. Jurnal Komunikasi. Volume 13, Nomor 1 Oktober 2018.

Rhodes, J.E., Lowe, SR., \& Schwartz, SEO. (2011). Mentor relationships. in: prinstein. Editor. Encyclopedia of Adolescence. San Diego: Academic Press.

Rohmawati, I. (2011). Faktor-Faktor yang Berhubungan Dengan Perilaku Wanita Usia Subur Dalam Deteksi Dini Kanker Serviks Metode IVA di Wilayah Kerja Puskesmas Ngawen 1 Kabupaten Gunung Kidul Tahun 2011. Skripsi. Jakarta: FKM UI.

Sari, K.P., Muslim, M.H., \& Ulfah, S. (2012). Kejadian Infeksi Gonorea Pada Pekerja Seks Komersial di Lokalisasi Pembantuan Kecamatan Landasan Ulin Banjarbaru. Jurnal Buski, Vol. 4 (1) : 29-35.

Sari, Y.P., Mulyanti, L.D., \& Oktriani, T. (2015). Pengaruh Pendidikan Kesehatan Reproduksi Menggunakan Metode Mentoring Terhadap Pengetahuan Remaja Tentang Kesehatan Reproduksi. Ners Jurnal Keperawatan, Vol 11, No 1 : 43-50.

Sulistiyowati, E.E. (2009). Analisis Pelaksanaan Mentoring Dalam Pembentukan Konsep Diri Pelajar SMA Pada Lembaga ILNA Youth Centre Bogor. Januari 2, 2019. Diaksespada http://EkoEndah Sulistiyowati.Pdf.

Taufia, D. (2017). Faktor-faktor yang Berhubungan dengan Perilaku Wanita Pasangan Usia Subur (PUS) dalam Deteksi Dini Kanker Leher Rahim Metode IVA Di Wilayah Kerja Puskesmas Nanggalo Padang Tahun 2017. 